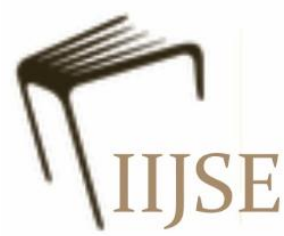

\title{
STUDI PENYIMPANGAN INTERNAL PADA BANK UMUM SYARIAH DI INDONESIA
}

\author{
Ernawati $^{1}$ \\ Universitas Halu Oleo \\ erna_unhalu@yahoo.com
}

\begin{abstract}
Abstrak
Kata kunci:

pertumbuhan;

fraud; strategi,

whistle blowing

system

Penelitian ini bertujuan untuk mengetahui dinamika penyimpangan internal (fraud pada Bank Umum Syariah di Indonesia. Penelitian menggunakan data sekunder periode 2011-2017 publikasi Bank Umum Syariah. Sampel penelitian terdiri dari 9 bank umum syariah yang ditentukan berdasarkan ketersediaan data. Analisis data digunakan berupa grafik, diagram, dan analisis pertumbuhan. Hasil penelitian menunjukkan bahwa penanganan kejadian fraud hanya berdampak selama 3 tahun. Angka kejadian fraud rata-rata selama periode penelitian sebesar 9,87 kasus per tahun per bank. Bank BCAS telah mampu menurunkan angka kejadian fraud mendekati nihil (zero fraud). Strategi penanganan fraud yang dilakukan oleh pihak Bank Umum Syariah yaitu menggunakan sarana pelaporan whistle blowing system yang dipergunakan oleh karyawan untuk melaporkan jika menemukan dan melihat perbuatan fraud yang dilakukan oleh karyawan. Pada sisi lain juga dibentuk unit kerja anti fraud. Namun efektifitas penerapan kedua strategi tersebut relatif berbeda pada setiap Bank Umum Syariah.
\end{abstract}

\section{Keyword:}

growth; fraud;

strategy; whistle-

blowing system 


\section{A. Pendahuluan}

Penyimpangan internal atau fraud merupakan perilaku yang tidak etis dan sebuah pelanggaran berat dalam bidang keuangan. Pada lembaga keuangan seperti perbankan, penyimpangan internal dapat menimbulkan dampak yang besar terhadap kelangsungan usaha, yang pada akhirnya dapat merugikan nasabah atau pelanggan. Laporan ACFE (2018) menunjukkan sektor perbankan merupakan sektor kedua tertinggi kejadian fraud di Asia Pasifik. Fraud tertinggi dialami oleh industri manufakatur atau sekitar 17 persen, sementara industri perbankan mengalami kejadian fraud sekitar 11 persen. Sementara perusahaan administrasi publik dan pemerintah berada pada posisi selanjutnya dengan jumlah 10 persen kasus. Dari jumlah fraud yang diteliti, Indonesia menempatu urutan ketiga terbesar jumlah kasus fraud setelah negara China dan Australia.

Fungsi perbankan sebagai lembaga intermediasi keuangan berdiri di atas kepercayaan nasabah sehingga responsif terhadap risiko reputasi. Penyimpangan intenal pada perbankan syariah masih dimungkinkan terjadi karena perilaku rent seeking behaviour karyawan. Kejadian tersebut akan menjadi pukulan keras pada lembaga tersebut yang menjalankan aktivitas perbankan berdasarkan prinsip syariah. Beberapa faktor yang mendorong fraud ditinjau dari triangle theory (Cressey, 1953) yaitu adanya tekanan, kesempatan, dan rasionalisasi. Teori tersebut menjadi rujukan utama berbagai peneliti untuk mengkaji faktor penentu kejadian fraud seperti Albrecht et al. (2010), Akindele (2011), Murphy and Dacin (2011), Dikolli (2012), dan Petter (2017). Pada perkembangan selanjutnya, kajian fraud memasukkan unsur-unsur ketaatan terhadap etika, khsusnya kajian fraud yang terjadi pada lembaga keuangan syariah. Sebagaimana studi Said dkk (2017) yang meneliti kasus fraud pada perbankan Islam di Malaysia menemukan bahwa nilai-nilai etika berpengaruh signifikan dan negatif terhadap kejadian fraud pada perbankan Islam. Begitupun halnya dengan variabel opportunity dan rationalization, namun tidak signifikan untuk variabel pressure.

Studi menganai kejadian fraud pada perbankan Islam di Indonesia juga telah diteliti sebelumnya. Hasil studi menunjukkan bahwa tata kelola yang baik tidak berpengaruh signifikan terhadap penyimpangan internal (Dinnul, dkk 2017; Haifa dan Rini 2016), sementara ketaatan terhadap prinsip syariah berpengaruh signifikan (Dinnul, dkk 2017; Haifa dan 
Rini 2016). Pengaruh ketaatan pada prinsip syariah menurunkan penyimpangan internal pada perbankan Islam di Indonesia pada penelitian Haifa dan Rini (2016) signifikan jika diproxi dengan profit sharing ratio.

Pada sisi lain, jika fraud telah terjadi, maka program yang paling efektif yang harus dilakukan oleh perbankan Islam guna menghindari kejadian berulang berdasarkan studi Rashidah dan Irda (2014) atas efektifitas pencegahan fraud pada perbankan Islam di Malaysia yaitu proteksi perangkat lunak/ aplikasi, disamping rekonsiliasi bank, perlindungan kata sandi dan review dan perbaikan pengendalian internal. Namun berapa lama waktu yang dibutuhkan untuk meminimalisasi kejadian fraud, masih minim dilakukan. Dengan demikian diperlukan sutu siklus pembelajaran mengenai pola waktu (lag) kejadian penyimpangan tersebut. Dalam hal ini berapa lama perbankan dapat memperbaiki sistem deteksi penyimpangan internal, dan berapa lama sistem tersebut berdampak pada aktivitas penyimpangan internal. Tulisan ini bertujuan untuk mengkaji dinamika penyimpangan internal pada kelompok Bank Umum Syariah di Indonesia.

\section{B. Metode Penelitian}

Penelitian menggunakan data sekunder publikasi laporan Good Corporate Governance (GCG) Bank Umum Syariah. Populasi penelitian berjumlah 13 Bank Umum Syariah, dan sampel penelitian ditentukan berdasarkan purposive sampling dengan pertimbangan ketersediaan data fraud yang dilaporkan pada periode 20112017. Dengan demikian, sampel BUS berjumlah 9 bank, yaitu: Bank Muamalat (BMI), Bank Victoria Syariah (BVS), Bank Mega Syariah (BMS), Bank Syariah Mandiri (BSM), Bank Rakyat Indonesia Syariah (BRIS), Bank Jabar Banten Syariah (BJBS), Bank Central Asia Syariah (BCAS), dan Panin Bank Syariah (PBS) serta Bank Negara Indonesia Syariah (BNIS). Alat analisis yang digunakan berupa grafik, diagram pie, dan pertumbuhan.

$$
G_{f}=\frac{\left(f_{t}-f_{t-1}\right)}{f_{t-1}} \times 100
$$

Keterangan:

$\mathrm{G}_{\mathrm{f}} \quad=$ pertumbuhan fraud

$\mathrm{f}_{\mathrm{t}} \quad=$ jumlah fraud periode $\mathrm{t}$

$\mathrm{F}_{\mathrm{t}-1} \quad=$ jumlah fraud periode $\mathrm{t}-1$ 


\section{Studi Literature}

Kecurangan yang dilakukan untuk memperoleh keuntungan yang bukan menjadi haknya dapat berupa: (1) kecurangan terhadap anak yatim ( An Nisa[4]: 10; Al An'am[6]: 152; Al Isra[17]: 34); (2) karyawan; (3) rekan bisnis; dan (4) masyarakat; dan (5) negara. Kecurangan ini merupakan dosa bagi seorang muslim, karena telah menzalimi manusia, sebagaimana Qs. al-Baqarah ayat 188: 11, yang artinya:

"Dan janganlah sebagian kamu memakan harta sebagian yang lain diantara kamu dengan jalan yang batil dan (janganlah) kaти membawa (urusan) harta itu kepada hakim, supaya kamu dapat memakan sebagian daripada harta benda orang lain dengan (jalan) berbuat dosa, padahal kamu mengetahui".

Islam mengakui bahwa manusia adalah makhluk yang lalai (Qs Yunus: 12; Qs Thaahaa: 115), namun kelalaian tersebut bukanlah fitrah manusia. Terlebih lagi jika kelalaian tersebut menyangkut perkara hak dan batil. Penyimpangan internal merupakan perkara batil sehingga diperlukan upaya dalam meminimisasi perilaku tidak etis tersebut. Minimisasi perilaku tidak etis, perlu diketahui faktor pembentuknya. Menurut Cressey (1953) terdapat 3 komponen yang memicu perilaku tidak etis dalam hal penyimpangan (fraud) yaitu: kesempatan, tekanan, dan rasionalisasi.

Kesempatan dapat timbul karena lemahnya pengendalian internal di organisasi, kurangnya pengawasan, dan/atau penyalahgunaan wewenang sehingga terbukanya kesempatan dapat menggoda individu atau kelompok yang sebelumnya tidak memiliki motivasi untuk melakukan fraud menjadi termotivasi melakukannya (Zulaikha dan Hadiprajitno, 2016). Adapun tekanan yang mendorong seseorang melakukan penyimpangan internal salah satunya kebutuhan. Menurut Maslow terdapat lima kebutuhan manusia berdasarkan hirarkinya, yaitu kebutuhan fisiologis, keamanan, sosial, penghargaan, dan kebutuhan aktualisasi diri. Sementara Aldefer memandang bahwa kebutuhan manusia terdiri dari kebutuhan eksistensi, kebutuhan yang dikaitkan dengan pihak lainnya, serta kebutuhan untuk tumbuh. (Khanza, 2017).

Konsep kebutuhan dalam Islam berbeda dengan Maslow dan Aldefer. Islam membedakan antara kebutuhan dan naluri. Pada umumnya, yang mendorong terjadinya fraud adalah kebutuhan atau masalah finansial, namun, banyak juga yang hanya terdorong oleh keserakahan (Zulaikha dan Hadiprajitno, 2016). Faktor selanjutnya 
yang mendorong fraud menurut Cressey (1953) yaitu rasionalisasi yang merupakan sikap, karakter, atau nilai-nilai etis yang membolehkan pihak tertentu untuk melakukan kecurangan. Rasionalisasi menjadi elemen penting dalam terjadinya fraud, yang merupakan pembenaran atas dindakan pelaku, misalnya karena rekan kerjanya melakukan hal yang sama dan tidak menerima sanksi atas tindakan fraud tersebut (Zulaikha dan Hadiprajitno, 2016). Dengan demikian, penyimpangan internal disebabkan oleh dua komponen utama, yaitu individunya dan sistemnya. Individu disini termasuk karakternya baik yang timbulkarena faktor kebutuhan maupun rasionalisasi. Sementara komponen kedua yaitu sistemnya. Menurut KBBI sistem merupakan perangkat unsur yang secara teratur saling berkaitan sehingga membentuk suatu totalitas. Unsur yang membentuk sistem dalam dunia perusahaan seperti peraturan, perangkat organisasi, metode, dan infrastruktur. Lemahnya sistem penganggulangan kecurangan dapat memberikan peluang kecurangan yang terus berulang. Salah satu cara yang dapat ditempuh untuk mengendalikan perilaku individu dalam melakukan penyimpangan khususnya pada Bank Umum Syariah yaitu peningkatan pemahaman atas perilaku etis di tempat kerja atau etos kerja Islam.

Ali (2015) mengungkapkan terdapat 5 (lima) dimensi etika kerja Islam, yaitu: dimensi spiritual, dimensi sosial, dimensi filosofis, dimensi pssikologis, dan dimensi ekonomi. Dimensi spiritual dari etika kerja Islam tercermin dalam hubungan terjalin dan dialektik antara kerja dan iman dan antara kerja dan penyempurnaan jiwa seseorang dari kebiasaan yang tidak diinginkan. Pada dimensi sosial terdapat kebutuhan untuk menjalin hubungan sosial dengan cara yang memfasilitasi kemakmuran, memudahkan kesusahan, dan memperkuat interaksi sosial diantara orang orang. Aspek filosofis etika kerja Islam mendorong hasil kerja berkontribusi pada kepentingan masyarakat dan memudahkan kehidupanorang orang. Karena alasan inilah, Islam tautan bekerja ke perkembangan di masyarakat yang tidak merusak sosial, ekonomi, dan keseimbangan psikologis. Dimensi psikologis etika kerja Islam untuk memperkuat identifikasi karyawan dengan profesi dan peran mereka sebagai warga negara yang produktif dalam masyarakat. Selanjutnya etika kerja Islam yang berdimensi ekonomi mengandung makna bahwa pekerjaan bukanlah suatu berakhir tetapi sarana untuk melayani minat seseorang dan meningkatkan kesejahteraan 
masyarakat. Perspektif ini menekankan hal itu kegiatan ekonomi dikenai sanksi, perorangan tidak boleh didorong oleh kepentingan pribadi terlepas dari apa yang dimiliki masyarakat, dan kebutuhan untuk terus memenuhi kebutuhan pasar yang terus berkembang.

Etika kerja Islam dapat berkontribusi pada peningkatan kinerja kekayaan dan kesejahteraan sosial (Ali and Al-Owaihan, 2008). Shukri dan Musa (2012) memandang bahwa salah satu point etos kerja Islam adalah amanah. Beberapa hasil empiris mengenai etika kerja Islam telah dilakukan sebelumnya. Siti, Kamaluddin and Salin (2015) menggunakan empat dimensi etika kerja Islam di perbankan, yaitu: usaha, kerja tim, kejujuran dan akuntabilitas. Hasil penelitian menunjukkan bahwa tidak terdapat perbedaan praktik etika kerja Islam pada karyawan bank Islam maupun bank konvensional. Beberapa studi mengkaji pengaruh etika kerja Islam baik terhadap output perusahaan, kepuasan kerja, maupun kehidupan sektor publik. Hasil penelitian Naresh et al. (2010) menunjukkan bahwa etika kerja Islam

\section{Hasil dan Pembahasan}

Kejadian Fraud Pada Bank Umum Syariah berpengaruh terhadap berpengaruh terhadap kapabilitas inovasi dalam sektor publik di Malaysia. Sementara studi Wahibur (2010) menunjukkan bahwa etika kerja Islam berpengaruh terhadap outcome perusahaan pada lembaga keuangan mikro syariah di Kabupaten Demak. Beberapa penelitian lain menguji pengaruh etika kerja Islam terhadap organisasi dan kepuasan kerja. Shakil (2011) meletakkan konsep bahwa rewards, konflik kerja, job turnover intentions, komitmen organisasi, dan kepuasan kerja yang berkorelasi dengan etika kerja Islam. Temuan ini sejalan dengan temuan Rokhman dan Omar (2008), serta Shahrul, et.al. (2016). Sementara Keumala dan Indra (2012) menemukan bahwa etika kerja Islam berpengaruh secara langsung terhadap motivasi intrinsik, kepuasan kerja, komitmen organisasi pada karyawan bank Islam di Bandar Lampung. Grbac dan Loncaric (2009) menemukan hubungan positif antara persepsi dari peranan etika dan tanggungjawab sosial dalam melakukan bisnis, maupun laba dan produktifitas

Kontribusi kejadian penyimpangan internal pada sampel bank umum syariah di Indonesia secara rata-rata 2011-2017 sebagaimana disajikan pada gambar 1 
menunjukkan bahwa proporsi terbesar kejadian fraud disumbang oleh BMS atau sebanyak 36\%, disusul oleh BSM dan BMI yang masing-masing sebesar 22\%. Proporsi kejadian fraud terendah disumbang oleh BCAS dan PBS.

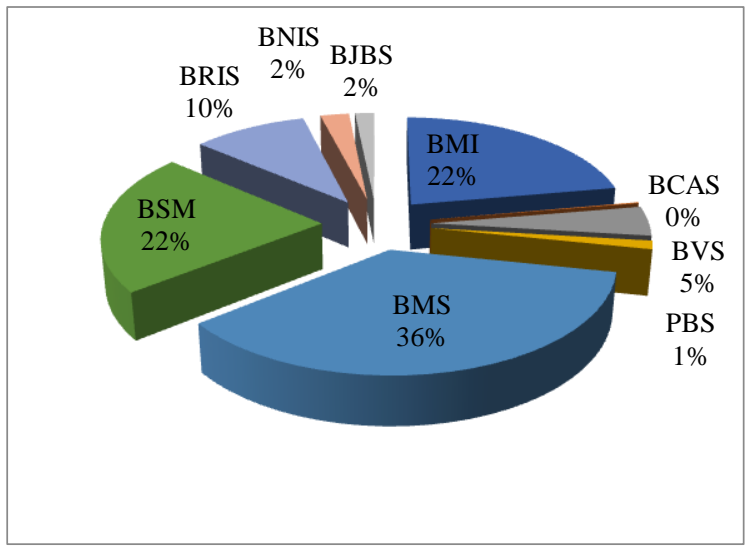

Sumber: Laporan GCG masing-masing bank, (20122018)

Gambar 1 Distribusi Penyimpangan Internal Berdasarkan JenisBank

Tabel 1 menunjukkan bahwa BMS, BSM dan BMI merupakan bank umum syariah yang mendominasi angka kejadian fraud. BMS bahkan sempat mengalami kejadian fraud sebesar 107 kasus, sementara BMI sebanyak 82 kasus dalam 1 tahun. Pada seluruh bank yang dijadikan sampel, terdapat BUS yang dapat meminimumkan kejadian fraud hingga hampir nihil (zero fraud) yaitu BCAS.
Tabel 1 Penyimpangan Internal Bank Umum Syariah di Indonesia

\begin{tabular}{lrrrr}
\hline Jenis Bank & Maks & \multicolumn{1}{c}{ Mi } & Mean & $\begin{array}{c}\text { Standar } \\
\text { Deviasi }\end{array}$ \\
\hline BMI & 82 & 0 & 19,57 & 30,36 \\
BCAS & 1 & 0 & 0,14 & 0,38 \\
BVS & 10 & 1 & 4,00 & 3,79 \\
PBS & 3 & 0 & 1,14 & 1,46 \\
BMS & 107 & 0 & 31,86 & 39,31 \\
BSM & 34 & 0 & 19,29 & 10,29 \\
BRIS & 21 & 0 & 8,57 & 7,46 \\
BNIS & 6 & 0 & 2,14 & 2,04 \\
BJBS & 7 & 0 & 1,43 & 2,70 \\
\hline TOTAL BUS & 144 & 19 & 87,57 & 45,15 \\
\hline \multicolumn{5}{c}{ Sumber: Laporan GCG masing-masing } \\
& bank (2012-2018), diolah & &
\end{tabular}

\section{Kebijakan Anti Fraud Bank Umum Syariah}

Penyimpangan internal tertinggi secara rata-rata dialami oleh BMS. Pada awal periode pengamatan penelitian tahun 2011, jumlah kejadian fraud pada BMS sebanyak 16 kasus. Kejadian ini dilakukan oleh oknum internal sebagai dampak ketidaktertiban pelaksanaan operating procedure $(S O P)$ dan kebijakan operasional dalam pelaksanaan kegiatan operasional, lemahnya supervisi dan tidak dilaksanakannya proses dual control, serta rendahnya awareness terhadap risiko. Untuk meminimalisir dan mengantisipasi fraud maka Direktorat Risk, Compliance \& HR telah menerapkan strategi anti fraud dengan cara antara lain: (1) kebijakan Whistle Blowing System Membudayakan 
pelaksanaan whistle blowing system kepada seluruh pegawai BMS sehingga memiliki kepedulian yang tinggi terhadap perusahaan dengan membuat pelaporan kepada Unit Khusus Banking Fraud jika melihat/mendengar terjadinya kasus fraud wilayah kerja; dan (2) Membentuk Unit Intelijen/Surveillance di Unit Khusus Banking Fraud yang melakukan pengamatan/pemeriksaan tanpa diketahui dan disadari oleh pihak yang diperiksa, guna mendukung kebijakan KYE mengenali pegawai dari sisi karakter, perilaku dan gaya hidup (BMS, 2011).

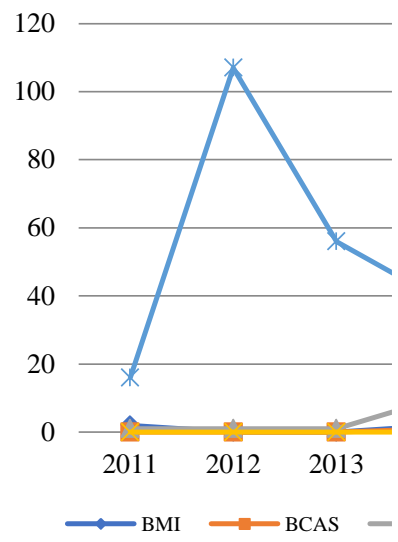

a. Penyimpangan Internal Bank Syariah Kepemilikan Swasta

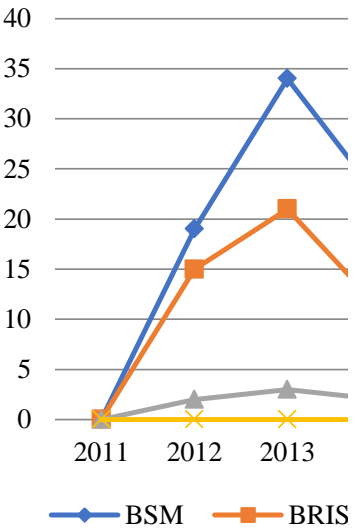

b. Penyimpanga n Internal Bank Syariah BUMN/BUM D

Sumber: Laporan GCG masing-masing bank 20112017, diolah

Gambar 2 Perkembangan Penyimpangan Internal Bank Umum Syariah Tahun 20112017
Namun kebijakan ini tampaknya tidak langsung menurunkan fraud pada BMS, yang ditunjukkan dengan melonjaknya jumlah fraud yang dilaporkan berdasarkan data GCG BMS pada tahun 2012 sebagaimana Gambar 2 sebanyak 107 kasus. Dari jumlah tersebut, tidak satupun yang diproses melalui jalur hukum. Kemudian pada tahun 2013 dan seterusnya kasus fraud di BMS terus mengalami penurunan hingga tahun 2015 hanya mencapai 1 kasus.

Pada sisi lain, kasus fraud kedua tertinggi yaitu dialami oleh Bank Mandiri Syariah (BSM) dengan rata-rata 26 kasus. Pada tahun 2012 BMS menerapkan model antisipasi fraud dengan semboyan "fraud adalah musuh BSM". Wujud keseriusan BSM memberantas fraud adalah adanya sarana pelaporan Whistle Blowing System ( $i$ BLOW) yang dipergunakan jajaran BSM untuk melaporkan setiap menemukan dan melihat perbuatan fraud yang dilakukan oleh jajaran BSM. Whistle Blowing System $(i \mathrm{BLOW})$ dirancang sebagai sarana pelaporan berbasis IT yang bersifat confidential untuk memudahkan jajaran BSM melaporkan setiap kejadian internal fraud tanpa harus merasa takut karena kerahasiaannya terjaga. Whistle Blowing System (iBLOW menjadi sarana pelaporan penting bagi jajaran BSM untuk membasmi 
fraud yang dilakukan internal BSM, sehingga kejadian/kasus dapat ditekan menjadi ke arah Zero Fraud. Dengan model ini terdapat 48 laporan masuk, dengan 25 kasus internal fraud berupa Meminta uang untuk proses pembiayaan kepada nasabah secara terang-terangan kepada nasabah (BSM, 2013). Pada tahun 2013 sistem Bwise ini diperkuat dengan melakukan audit khusus fraud, dengan jumlah audit sebagaimana disajikan pada Tabel 2 . Penerapan sistem B-Wise sejak 2012 tampaknya telah mendorong penurunan kasus fraud pada 1 tahun pasca pemberlakuannya.

Tabel 2 Rencana dan Realisasi Audit Tahunan BSM Tahun 2013

\begin{tabular}{|c|c|c|c|c|}
\hline $\begin{array}{l}\text { Ketera } \\
\text { ngan }\end{array}$ & $\begin{array}{l}\text { Ruti } \\
\text { n }\end{array}$ & $\begin{array}{l}\text { Tem } \\
\text { atik }\end{array}$ & $\begin{array}{l}\text { Khusus/ } \\
\text { Fraud }\end{array}$ & Total \\
\hline $\begin{array}{l}\text { Rencan } \\
\text { a Audit } \\
\text { Tahuna } \\
\mathrm{n}\end{array}$ & 139 & 9 & 50 & 198 \\
\hline $\begin{array}{l}\text { Realisa } \\
\text { si Audit }\end{array}$ & 145 & 4 & $\left.75^{*}\right)$ & 224 \\
\hline $\begin{array}{l}\text { Pencap } \\
\text { aian }\end{array}$ & $\begin{array}{r}104,3 \\
2 \%\end{array}$ & $\begin{array}{r}44,44 \\
\%\end{array}$ & $150,00 \%$ & $\begin{array}{r}150,0 \\
0 \%\end{array}$ \\
\hline
\end{tabular}

Pada BRIS, kasus penyimpangan yang telah mengalami kenaikan signifikan sejak tahun 2012, dan mencapai puncaknya pada tahun
2013. Kebijakan anti fraud BRIS yang diterapkan pada tahun 2012 menunjukkan bahwa BRIS telah melaksanakan mekanisme anti fraud management sesuai dengan SE BI 13/28/DPNP tentang penerapan strategi anti fraud bagi bank umum. Pada periode ini bank telah memiliki dan menerapkan kebijakan khusus tentang fraud manajemen yang didukung dengan pembentukan satuan kerja anti fraud (SKAF) serta infrastruktur lainnya tentang wistle blower dan ketentuan pengenaan sanksi bagi karyawan yang melakukan fraud. Namun tampaknya kebijakan ini belum dapat menurunkan jumlah kasus fraud di BRIS pada periode selanjutnya, dan mulai bekerja pada 2 periode selanjutnya, yaitu tahun 2014 yang menunjukkan penurunan fraud hingga 50 persen dari periode sebelumnya.

BNIS merupakan salah satu BUS yang mengalami kasus terendah selama periode pengamatan dengan rata-rata sebanyak 2 kasus per tahun. Hal ini menunjukkan Unit Anti Fraud BNI yang bertugas menangani penerapan strategi anti fraud berjalan lebih efektif. Unit Anti Fraud ini juga didukung kebijakan Whistle Blowing System sebagai sarana pelaporan penyimpangan/pelanggaran yang bersifat rahasia dan memiliki mekanisme perlindungan pelapor. 


\section{Lama Waktu Penyesuaian Kejadian Fraud} Hasil estimasi penyesuaian kejadian fraud pada bank umum syariah di Indonesia disajikan sebagaimana Gambar 3 yang menunjukkan bahwa puncak kejadian fraud pada tahun 2012 berimplikasi pada penurunan tahun-tahun selanjutnya. Namun penurunan kasus fraud hanya bertahan pada 3 periode. Kejadian fraud periode 2012 meningkat sekitar 700 persen, dan kemudian menurun dengan pertumbuhan negatif pada tahun setelahnya yaitu 2013 -2015. Angka kejadian fraud kemudian meningkat pada tahun 2016, dan menurun kembali setelahnya. Kontribusi utama pertumbuhan fraud pada tahun 2012 bersumber dari BMS dengan pertumbuhan fraud sebesar 569 persen. Pertumbuhan fraudpada 2012 tersebut juga dialami oleh seluruh BUS relasi BUMN yaitu BSM, BRIS dan BNIS.

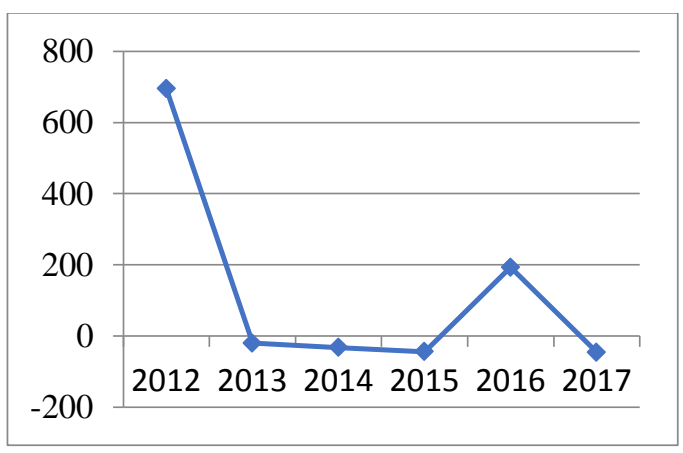

Sumber: Hasil Penelitian 2019
Gambar 3 Pertumbuhan Kejadian Fraud Pada Bank Syariah di Indonesia

Pertumbuhan negatif fraud pada tahun 20132015 dipicu penurunan fraud pada BMS dari 107 kasus menjadi 56 kasus pada tahun 2013, dan menurun kembali menjadi 39 kasus pada 2014, dan penurunan tersebut berlanjut hingga tahun 2015 dengan jumlah kasus nihil atau zero fraud. Pola tersebut juga dialami oleh BSM yang pada tahun 2013 memiliki angka kejadian fraud sebanyak 34, kemudian menjadi 22 pada tahun 2014 dan menurun menjadi 18 pada tahun 2015. Namun pada tahun 2016 ratarata angka kejadian fraud mengalami peningkatan. Pertumbuhan fraud pada tahun 2016 didorong oleh meningkatnya kejadian fraud pada BMI yang mencapai 86 kasus atau meningkat sebesar 412 persen dari tahun sebelumnya. Beberapa BUS lainnya yang mengalami peningkatan kejadian fraud pada tahun 2016 yaitu BSM, BRIS, BNIS, BJBS, dan BMS. Selanjutnya pada pengamatan periode terakhir, yaitu 2017 menunjukkan penurunan rata-rata kejadian fraud sebesar negatif 46,03 persen yang didorong oleh pertumbuhan negatif kejadian fraud pada BMI sebesar negatif 65\% dan BSM sebesar negatif $83 \%$. 


\section{Pembahasan}

Fraud yang tidak tertangani dengan baik pada periode sebelumnya akan mendorong peningkatan fraud periode selanjutnya. Perilaku ini didorong oleh moral hazard pelaku maupun karyawan lain. Dengan demikian penyimpangan yang dilakukan seseorang dapat menular antar waktu dan antar individu. Persoalan fraud bukan hanya perkara individu pegawai namun juga kelemahan sistem yang ada. Studi juga menunjukkan bahwa kejadian fraud yang dapat ditangani pada peride berjalan akan berdampak pada tiga periode berikutnya, dan meningkat kembali pada periode berikutnya. Hal ini menunjukkan bahwa ketika pihak perbankan telah menyadari kejadian fraud dan melakukan upaya-upaya penanganan, maka efeknya hanya berdampak selama 3 tahun, selanjutnya akan meningkat kembali setelahnya. Peningkatan kembali kejadian fraud dapat terjadi baik karena beberapa faktor seperti: penurunan efek pembelajaran atas sanksi yang diberikan, kelemahan sistem baru yang diterapkan, ataupun karena faktor lain. Pada skala individu, peningkatan standar etika dan nilai Islam penting untuk ditekankan.

Studi Said dkk (2017) yang meneliti kasus fraud pada perbankan Islam di Malaysia menemukan bahwa nilai-nilai etika berpengaruh signifikan dan negatif, artinya semakin tinggi pemahaman nilai-nilai Islam seseorang, makan akan menurunkan perilaku fraud pada karyawan. Studi Said dkk (2017)sejalan dengan Dinnul, dkk (2017); Haifa dan Rini (2016). Sistem pananganan fraud dalam bentuk adaptasi strategi whistle blowing system dan unit kerja anti fraud perlu terus didorong guna meminimisasi kesempatan (opportunity) karyawan dalam melakukan perilaku tidak etis, termasuk fraud. Hasil penelitian Said dkk (2017) menemukan bahwa variabel opportunity signifikan terhadap perilaku penyimpangan internal karyawan perbankan syariah,s ementara penelitian Dinnul, dkk (2017); dan Haifa dan Rini (2016) menunjukkan bahwa tata kelola yang baik tidak berpengaruh signifikan terhadap penyimpangan internal. Dengan demikian penanganan fraud perlu dilakukan secara menyeluruh baik peningkatan kesadaran individu, maupun perbaikan dan peninjauan kembali sistem yang diterapkan. Karena memperbaiki sistem tanpa perbaikan individu masih membuka peluang kejadian fraud, begitupun sebaliknya

\section{Penutup}

\section{KESIMPULAN}

Fraud dapat menyebar antar individu dan antar waktu . Angka kejadian fraud rata-rata 
selama periode penelitian sebesar 9,87 kasus per tahun. Bank BCAS telah mampu menurunkan angka kejadian fraud mendekati nihil (zero fraud). Sementara kasus fraud tertinggi dialami oleh BMS,disusul oleh BMI dan BSM. Strategi penanganan fraud yang dilakukan oleh pihak Bank Umum Syariah yaitu sarana pelaporan whistle blowing system yang dipergunakan oleh karyawan untuk melaporkan jika menemukan dan melihat perbuatan fraud yang dilakukan oleh karyawan. Pada sisi lain juga dibentuk unit kerja anti fraud. Namun efektifitas penerapan kedua strategi tersebut relatif berbeda pada setiap BUS. Penanganan kejadian fraud hanya berdampak selama 3 tahun, sehingga penanganan fraud selain memiliki target individu, juga target yang lebih besar yaitu pembaharuan sisitem secara menyeluruh dan terus menerus

\section{E. Daftar Pustaka}

ACFE (2018) Report to The Nations 2018 Global Study on Occupational Fraud and Abuse, Asia-Pacific Edition. Tersedia pada https://www.acfe.com

ACFE. (2014). Report to the Nations on Occupational Fraud and Abuse, 2014 Global Fraud Study. ACFE Publisher. Retrieved from https://www.acfe.com

Akindele, R. I. (2011). Fraud as a negative catalyst in the Nigerian banking industry. Journal of Emerging Trends in Economics and Management Sciences, 2(5), 357-363.

Albrecht, C., Turnbull, C., Zhang, Y., \& Skousen, C. J. (2010). The relationship between South Korean chaebols and fraud. Management Research Review, 33(3), 257-268.

Ali, A. J. (2015) Islamic Work Ethic in a Dynamic World. Religions, 11-21. Tersedia pada http://www.qscience.com/doi/pdf/10. 5339/rels.2015.work.11

Ali, A. J. \& Al-Owaihan, A. (2008). Islamic work ethic: a critical review. Cross Cultural Management: An International Journal, Vol: 15. Issue: 1.

Bank Central Asia Syariah (2018) Laporan Good Corporate Governance 2017. BCAS. Tersedia pada https://www.bcasyariah.co.id

Bank Central Asia Syariah (2016) Laporan Good Corporate Governance 2015. BCAS. Tersedia pada https://www.bcasyariah.co.id

Bank Central Asia Syariah (2014) Laporan Good Corporate Governance 2013. BCAS. Tersedia pada https://www.bcasyariah.co.id

Bank Central Asia Syariah (2012) Laporan Good Corporate Governance 2011. BCAS. Tersedia pada https://www.bcasyariah.co.id

Bank Jabar Banten Syariah (2018) Laporan Good Corporate Governance 2017. BJBS. Tersedia pada https://www.bjbsyariah.co.id

Bank Jabar Banten Syariah (2016) Laporan Good Corporate Governance 2015. BJBS. Tersedia pada https://www.bjbsyariah.co.id

Bank Jabar Banten Syariah (2014) Laporan Good Corporate Governance 2013. BJBS. Tersedia pada https://www.bjbsyariah.co.id 
Bank Jabar Banten Syariah (2012) Laporan Good Corporate Governance 2011. BJBS. Tersedia pada https://www.bjbsyariah.co.id

Bank Mega Syariah (2018) Laporan Good Corporate Governance 2017.BMS. Tersedia pada https://www.megasyariah.co.id

Bank Mega Syariah (2016) Laporan Good Corporate Governance 2015.BMS. Tersedia pada https://www.megasyariah.co.id

Bank Mega Syariah (2014) Laporan Good Corporate Governance 2013.BMS. Tersedia pada https://www.megasyariah.co.id

Bank Mega Syariah (2012) Laporan Good Corporate Governance 2011.BMS. Tersedia pada https://www.megasyariah.co.id

Bank Muamalat Indonesia (2018) Laporan

Good Corporate Governance 2017.

Bank Muamalat Indonesia. Tersedia

pada

https://www.bankmuamalat.co.id

Bank Muamalat Indonesia (2016) Laporan Good Corporate Governance 2015. Bank Muamalat Indonesia. Tersedia pada https://www.bankmuamalat.co.id

Bank Muamalat Indonesia (2014) Laporan Good Corporate Governance 2013. Bank Muamalat Indonesia. Tersedia pada https://www.bankmuamalat.co.id

Bank Muamalat Indonesia (2012) Laporan Good Corporate Governance 2011. Bank Muamalat Indonesia. Tersedia pada https://www.bankmuamalat.co.id

Bank Negara Indonesia Syariah (2018) Laporan Good Corporate
Governance 2017.BNIS. Tersedia pada https://www.bnisyariah.co.id

Bank Negara Indonesia Syariah (2016) Laporan Good Corporate Governance 2015.BNIS. Tersedia pada https://www.bnisyariah.co.id

Bank Negara Indonesia Syariah (2014) Laporan Good Corporate Governance 2013.BNIS. Tersedia pada https://www.bnisyariah.co.id

Bank Negara Indonesia Syariah (2012) Laporan Good Corporate Governance 2011.BNIS. Tersedia pada https://www.bnisyariah.co.id

Bank Rakyat Indonesia Syariah (2018) Laporan Good Corporate Governance 2017.BRIS. Tersedia pada https://www.brisyariah.co.id

Bank Rakyat Indonesia Syariah (2016) Laporan Good Corporate Governance 2015.BRIS. Tersedia pada https://www.brisyariah.co.id

Bank Rakyat Indonesia Syariah (2014) Laporan Good Corporate Governance 2013.BRIS. Tersedia pada https://www.brisyariah.co.id

Bank Rakyat Indonesia Syariah (2012) Laporan Good Corporate Governance 2011.BRIS. Tersedia pada https://www.brisyariah.co.id

Bank Syariah Mandiri (2018) Laporan Good Corporate Governance 2017. BSM. Tersedia pada https://www.syariahmandiri.co.id

Bank Syariah Mandiri (2016) Laporan Good Corporate Governance 2015. BMS. Tersedia pada https://www.syariahmandiri.co.id

Bank Syariah Mandiri (2014) Laporan Good Corporate Governance 2013. BMS. Tersedia pada https://www.syariahmandiri.co.id

Bank Syariah Mandiri (2013) Laporan Good Corporate Governance 2012. BMS. Tersedia pada https://www.syariahmandiri.co.id 
Bank Syariah Mandiri (2012) Laporan Good Corporate Governance 2011. BMS. Tersedia pada https://www.syariahmandiri.co.id

Bank Victoria Syariah (2018) Laporan Good Corporate Governance 2017. BVS. Tersedia pada https://www.bankvictoriasyariah.co.i $\underline{\mathrm{d}}$

Bank Victoria Syariah (2016) Laporan Good Corporate Governance 2015. BVS. Tersedia pada https://www.bankvictoriasyariah.co.i d

Bank Victoria Syariah (2014) Laporan Good Corporate Governance 2013. BVS. Tersedia pada https://www.bankvictoriasyariah.co.i d

Bank Victoria Syariah (2012) Laporan Good Corporate Governance 2011. BVS. Tersedia pada https://www.bankvictoriasyariah.co.i d

Cressey, Donald R. 1953. Others People Money, A Study In The Social Psychology of Embezzlement. Montclain, JN; Patterson Smith

Departemen Agama RI (2010) Al-Qur'an dan Terjemahan, Bandung: $\mathrm{CV}$ Diponegoro.

Dikolli, S. S., Mayew, W.J., \& Steffen, T.D. (2012). Honoring One's Word: CEO Integrity and Accruals Quality. Retrieved from http://fbe.usc.edu/FEApapers/ACC1 $\% 20 \quad$ Manuscript $\%$ 2092\%20Shane\%20 Dikolli\%20 duke.pdf

Dinnul, A.A., Fernando A., Ricardo P., dan Siti Khairani (2017) Relevansi Fraud Triangle pada Bank Syariah. Paper dipresentasikan pada Simposium Nasional Akuntansi XX, Jember, 2017

Grbac, B. \& Loncaric, D. (2009). Ethics, social responsibility and business performance in a transition economy. Business, Vol: 4, Issue: 2, pp. 143 - 158

Haifa, N. dan Rini (2016). Analisis Faktor yang Mempengaruhi Fraud di Bank Syariah Paper di presentasikan pada Simposium Nasional Akuntansi XIX, Lampung, 2016

KBBI (online)

Sistem. https://kbbi.web.id/sistem. Diakses pada 16 Mei 2019

Keumala, H. dan Indra C. (2012) Islamic Work Ethic: The Role of Intrinsic Motivation, Job Satisfaction, Organizational Commitment and Job Performance. International Congress on Interdisciplinary Business and Social Science (ICIBSoS). Procedia Social and Behavioral Sciences 65 ( 2012 ), 272 - 277. doi: 10.1016/j.sbspro.2012.11.122

Khanza, Savitra (2017) Lima Teori-Teori Motivasi Menurut Para Ahli.

Tersedia pada: https://dosenpsikologi.com/teoriteori-motivasi. Diakses pada $16 \mathrm{Mei}$ 2019

Murphy, P.R. \& Dacin, M.T. J (2011). Psychological Pathways to Fraud: Understanding and Preventing Fraud in Organizations. Journal of Business Ethics, 101(4), 601-618

Naresh. K., Raduan, C.R., (2010), Examining the link between Islamic Work Ethics and Innovation capability, Journal of Management Development, Vol. 29 (1), 79-93

Panin Bank Syariah (2018) Laporan Good Corporate Governance 2017. PBS. Tersedia pada https://www.paninbanksyariah.co.id

Panin Bank Syariah (2016) Laporan Good Corporate Governance 2015. PBS. Tersedia pada https://www.paninbanksyariah.co.id

Panin Bank Syariah (2014) Laporan Good Corporate Governance 2013. PBS. 
Tersedia

pada https://www.paninbanksyariah.co.id

Panin Bank Syariah (2012) Laporan Good Corporate Governance 2011. PBS. Tersedia pada https://www.paninbanksyariah.co.id

Petter, Gottschalk. (2017) White-Collar Crime Triangle: Finance, Organization and Behavior. $\mathbf{J}$ Forensic Sci \& Criminal Inves 4(2): 555635 .

DOI: 10.19080/JFSCI.2017.04.555635.

Rashidah, A.R. dan Irda S.K.A. (2014) Effectiveness of fraud prevention and detection techniques in Malaysian Islamic banks. Procedia Social and Behavioral Sciences 145 (2014), 97 - 102

Rokhman, W. \& Omar, A. (2008). The Effect of Islamic Work Ethics on Job Satisfaction, Organizational Commitment and Turnover Intention: A Study on Islamic Microfinance Institutions in Central Java, Indonesia. Journal Bisnis \& Manajemen, Vol. 4, No. 1.

Said, J., Alam, M.M., Ramli, M., \& Rafidi, M. (2017). Integrating ethical values into fraud triangle theory in assessing employee fraud: Evidence from the Malaysian banking industry. Journal of International Studies, 10(2), 170184. doi:10.14254/20718330.2017/10-2/13

Shakil, M.A (2011). Work Ethics: An Islamic Prospective. International Journal of Human Sciences [Online]. 8(1): $\quad 850-859 \quad$ Available: http://www.insanbilimleri.com/en
Shukri, A. dan Musa, Y.O (2012) The Concept of Islamic Work Ethic: An Analysis of Some Salient Points in the Prophetic Tradition, International Journal of Business and Social Science, Vol 3 (20), 116-123

Shahrul N.S., Siti S.B., Muhammad S.A., dan Abdullah O. (2016) The Effect of Islamic Work Ethics on Organizational Commitment. 7th International Economics \& Business Management Conference, 5th \& 6th October 2015. Procedia Economics and Finance 35 ( 2016 ) $582-590$

Siti A.M.K., Kamaluddin N., and Salin, A.S.A.P. (2015) Islamic Work Ethics (IWE) Practice among Employees of Banking Sectors. Middle-East Journal of Scientific Research 23 (5): 924-931.

DOI: 10.5829/idosi.mejsr.2015.23.05.2217 3

Wahibur Rokhman (2010) The Effect of Islamic Work Ethics on Work Outcomes, EJBO Electronic Journal of Business Ethics and Organization Studies Vol. 15, No. 1, 21-27

Zulaikha dan Hadiprajitno, PTB (2016).

Faktor-Faktor yang Memengaruhi Procurement Fraud: Sebuah Kajian dari Perspektif Persepsian Auditor Eksternal. Jurnal Akuntansi dan Keuangan Indonesia, Desember 2016, Vol. 13( 2), hal 194 - 220 